\title{
Explaining Citizen Perceptions of Party Ideological Positions: The Mediating Role of Political Contexts*
}

\author{
Royce Carroll \\ University of Essex \\ r.carroll@essex.ac.uk \\ Hiroki Kubo \\ Osaka University \\ kubo@osipp.osaka-u.ac.jp
}

\begin{abstract}
In this paper we examine how political contexts mediate citizens' ability to understand political parties' ideological positions, focusing on education level. Using cross-national data from the Comparative Study of Electoral Systems (CSES), we build on the approach developed by Palfrey and Poole (1987) to study individuals' ability to place parties in on a 'left-right' spectrum. We explore how the effect of individual education level is mediated by contextual factors in influencing the supply and clarity of 'left-right' information in a party system. The results show that the effect of education levels in improving citizens' ability to perceive party ideological locations is conditional on political context. First, in cases where the supply of such information is limited due to less democratic experience and less programmatic party politics, the effect of education is weakened. However, the effect of education increases in the contexts where we expect less clarity of party position informationwhere parties are least polarized and where institutional factors add complexity to party competition.
\end{abstract}

*The authors benefited from helpful comments from Petra Schleiter, Neil Vilsavanich, Nick Vivyan, Patrick Kuhn, Radoslaw Zubek and several anonymous reviewers, as well as participants at seminars at University of Missouri Kansas City, the University of Essex, Oxford University, and Durham University. 


\section{Introduction}

Without ideological labels, programmatic party representation would be difficult or impossible. Party positions are the political information that capture the policy implications of parties (Dalton, Farrell and McAllister, 2011; Klingemann, 2009; Powell, 2013) and facilitate policy-based mandates and accountability (Przeworski, Stokes and Manin, 1999; Adams et al., 2004; McDonald and Budge, 2005; Budge, 2012). As a result, party positions are widely regarded as a central part of policy-based party competition and vote choices. A large amount of existing research shows that citizens' perceptions of party ideological locations influence how they vote (Merrill and Grofman, 1999; Adams, Merrill III and Grofman, 2005; Thomassen, 2005; Kedar, 2005; Duch, May and Armstrong, 2010; Carlin, Singer and Zechmeister, 2015). However, with important exceptions (Granberg and Holmberg, 1988; Merrill, Grofman and Adams, 2001; Dahlberg, 2013; Zakharova and Warwick, 2014), we know less about how the factors that affect citizens perception of ideological information about parties vary across countries.

In this paper, we focus on how political sophistication affects the ability to correctly

perceive political parties' ideological positions. Specifically, we focus on how these effects are conditioned by political contexts. Our central argument is that the effect of political sophistication should be mediated by macro-level variables influencing both the supply and clarity of information. These, we argue, represent distinct mechanisms. While a limited supply of information reduces the effectiveness of sophistication in explaining the accuracy of left-right perceptions, increased clarity of information decreases its importance.

To examine this empirically, we make use of data from the Comparative Study of Electoral Systems (CSES). This broad cross-national sample of democracies including multiple regions allows us to examine how a variety of political contexts influence the information obtained by citizens about the ideological position of political parties. We use AldrichMcKelvey scaling (Aldrich and McKelvey, 1977; Palfrey and Poole, 1987; Hare et al., 2015) 
to estimate perceived party left-right positions adjusted for individual perceptual bias and generate a measure of party ideological misperception. We analyze the correlates of this misperception using a multilevel regression model combining individual and country-level variables. We find that education level is an important determinant of citizen perception, but that this effect depends on several factors associated with the supply and clarity of ideological information. Contexts where democracy is long established and parties are more programmatic improve the underlying amount of ideological information available, which results in an increase in the importance of education as a predictor of accuracy. Without such information, the effect of education is no longer present. The importance of education further depends on the clarity of how this information is transmitted, where education level is more important in presidential and federal institutional contexts. Finally, the effect of education lessens as the party system is more polarized-where party differentiation clarifies ideological distinctions between parties.

\section{Individual Sophistication and Ideological Information}

Scholars have long been interested in how citizens perceive the ideology of politicians. The notion of examining ideological placement on a spatial scale dates back to early studies of voting behavior in the US (Campbell et al., 1960) concerned with the lack of consistency in the ideological structure evident in voters' perceptions (Converse, 1964). In matters such as participation, variation in the US case has often been attributed to individual characteristics (Verba and Nie, 1972; Verba, Nie and Kim, 1978; Brady, Verba and Schlozman, 1995). Prominent among these factors is "political sophistication," which is often correlated with (but not necessarily causally resulting from) measures of educational attainment (Neuman, 1986; Luskin, 1987, 1990; Carpini and Keeter, 1996; Mondak, 1999, 2001; Goren, 2004; Highton, 2009). Political sophistication has become a key concept in the field of individual political decision-making and voting behavior 
(Neuman, 1986; Luskin, 1987, 1990; Carpini and Keeter, 1996).

An influential literature finds that politically sophisticated voters are better able to use the information "short cuts" to obtain ideological information (Sniderman, Brody and Tetlock, 1993; Popkin, 1994; Brady, Verba and Schlozman, 1995; Carpini and Keeter, 1996; Lupia and McCubbins, 1998; Lau and Redlawsk, 2001, 2006). In particular, Lupia and McCubbins (1998) emphasize the role of institutional design (electoral, legislative, and executive institutions) in enhancing citizen's ability to use heuristics to make decisions efficiently. Lau and Redlawsk $(2001,2006)$ indicate that partisanship and ideology are key sources of political heuristics that enhance voters' decision making process in combination with political sophistication. In general, less politically sophisticated voters should be in a weaker position to use such information to identify ideological distinctions among parties.

Various individual characteristics such as cognitive ability, socialization and engagement influence political sophistication. Since similar factors also influence educational attainment, it has often served as an indirect means of capturing the ability of citizens to make use of political information. Assuming that the relationship between education and political sophistication means the former can serve as a proxy for the latter, previous research would lead us to expect that the more educated citizens within a country should better able to identify party locations on average.

While the level of education may explain the variation in knowledge of left-right party placement within a country, contextual factors that vary across countries should change how this effect functions. Without complete knowledge of political information, voters rely on certain information as heuristics for making "reasonable" political choices (Conover and Feldman, 1989; Sniderman, Brody and Tetlock, 1993; Popkin, 1994; Lupia, 1994; Lupia and McCubbins, 1998; Lau and Redlawsk, 2001, 2006). In comparative perspective, the role of institutional design (Lupia and McCubbins, 1998) as well as party and ideological heuristics (Lau and Redlawsk, 2001) are important. These institutional and partisan factors shape voters' perception of party ideological positions and vary across country 
contexts. Thus, both the underlying supply of information and the clarity of transmission of information are critical to political perceptions. If party ideological label information is weakly developed, counteracted by party behavior, or complicated by the institutions in which parties compete, party labels are likely to be less effective in conveying party positions.

How does the macro-level context modify the effect of political sophistication on individual voters' political perception? Studies in comparative politics have examined systemlevel factors regulating the linkage between citizens and parties (Przeworski, Stokes and Manin, 1999; Powell, 2000; Strøm, Müller and Bergman, 2003; McDonald and Budge, 2005; Budge, 2012). Especially in advanced democracies, considerable research has examined the estimation of voters' and parties' positions, and the alignment between these (Merrill and Grofman, 1999; Adams, Merrill III and Grofman, 2005; Kedar, 2005; Duch, May and Armstrong, 2010). Survey data from the Comparative Study of Electoral Systems (CSES) has been especially useful to clarifying these voter-party linkages (Klingemann, 2009; Dalton and Anderson, 2011; Dalton, Farrell and McAllister, 2011), particularly with regard to how left-right party positions affect voting choice. Thus, we know there is a great deal of variation in ideological structure across countries and regions (Horowitz and Browne, 2005; Dalton, 2006; Hellwig, 2008; Linzer, 2008, 2011; Lupu and Riedl, 2013). Though not necessarily focused on perceptions of party ideological information, some cross-national research has focused on political knowledge emphasizing macro factors (Gordon and Segura, 1997; Grönlund and Milner, 2006) while others have shown that the level of voters' political sophistication conditions electoral accountability, particularly in new democracies (Duch, 2001; Gomez and Wilson, 2006).

In a pioneering study of the relationship between political sophistication and party system perceptions, Granberg and Holmberg (1988) examines the US and Sweden and concludes that the perceptual consensus in party placement is higher in Sweden than in the US due to the differences in ideological structure and party systems (See also Granberg 
1987; Listhaug, Macdonald and Rabinowitz 1994.). More recent research analyzes how individual voters evaluate parties, such as party attachment (Huber, Kernell and Leoni, 2005), assimilation and contrast (Merrill, Grofman and Adams, 2001; Drummond, 2010), valance judgment (Warwick and Zakharova, 2013), perceived polarization (Lupu, 2014), and perceptual agreement (Dahlberg, 2009).

Here, we focus on the factors that condition the relationship between political sophistication conditions and voters' perception of party positions by using the broadest available sample. As this sample includes countries outside of the set of established advanced democracies, we can investigate a variety of structural characteristics of political systems, such as the effect of democratic experience, party system linkages, and polarization, as well as institutional features such as presidentialism, federalism, and electoral systems. In the following sections, we review the contextual factors that might enhance or detract from the supply and clarity of the information available to voters to identify party positions, and thus influence the role of political sophistication.

\section{Political Contexts}

\section{Structural factors influencing The Supply of Ideological Informa- tion}

The first type of contextual factor we consider are those that should regulate the underlying supply of ideological information. We consider two related factors that are likely to affect this: democratic experience and programmatic party linkages. Both relate to the structural factors shaping the political context, such as economic development and political institutionalization (Duch, 2001; Gomez and Wilson, 2006; Dalton and Weldon, 2007; Mainwaring and Zoco, 2007; Hellwig, 2008, 2014; Hicken and Kuhonta, 2011; Kitschelt and Kselman, 2013; Lupu and Riedl, 2013; Gélineau, 2013). Democratic experience influ- 
ences the supply of party ideological information, where older democracies should provide more information on ideological locations. The use of this information, meanwhile, should be related political sophistication. Thus, we suggest that these information "supply" factors interact with individuals' sophistication in affecting levels of information on party ideology. We expect that countries with less democratic experience, which implies less institutionalized parties (Mainwaring and Zoco, 2007; Duch, 2001; Gomez and Wilson, 2006), would provide contexts with less ideological information in party labels for voters to assess. Because this difficulty relates to the underlying supply of information, the advantages of political sophistication should be limited.

Similarly, we also consider the policy-based or clientelistic nature and of party competition. At the system level, the strength of ideological connections between parties and voters is often thought to be regulated by the degree to which a system is characterized by programmatic politics, which in turn is associated with parties with clearer policy reputations (Kitschelt, 2000; Stokes, 2005; Keefer, 2007; Kitschelt and Wilkinson, 2007; Hicken, 2011; Kitschelt et al., 2010; Stokes et al., 2013; Harbers, de Vries and Steenbergen, 2013). Where clientelistic linkages are present and/or electoral mobilization is more focused on distributive politics or patron-client loyalties, we would expect party labels to have supplied less useful ideological information.

In either case, then, the effect of political sophistication - which depends on the presence of useful information for sophisticated citizens to obtain — should be diminished in weakly institutionalized or less programmatic environments. Without such underlying information being supplied with sufficient quality or quantity, the advantages of political sophistication should not be clear. 


\section{Institutional and Party System Factors influencing the Clarity of Ideological Information}

Next we consider factors that should affect how clearly party ideological information is transmitted to voters. These are the institutions and party system features that can blur party ideological information, increasing the importance of political sophistication. Institutional factors affect how democratic linkages between voters and parties function (Powell Jr and Whitten, 1993; Samuels and Hellwig, 2004; Hellwig and Samuels, 2008), including how voters obtain information from elites (Lupia and McCubbins, 1998). In particular, Lupia and McCubbins (1998) note how institutional design enables successful delegation relationships between citizens and elites. We elaborate on this notion, focusing on three institutional factors - presidentialism, federalism, and the electoral systemwhich may affect the clarity of party labels.

First, the candidate-centered nature of electoral systems is often thought to weaken the relationship between voters and parties. While party-centric electoral systems might enhance the clarity of party labels, it may be less clear under a candidate-centric electoral system, where voters would also rely to some extent on information about candidates (Carey and Shugart, 1995; Shugart, 2005; Shugart, Valdini and Suominen, 2005; Farrell and McAllister, 2006; Schmidt, 2009; Carey, 2009).

Second, presidential systems can complicate the relationship between voters and parties (Samuels, 2004; Hellwig and Samuels, 2008; Carey, 2009; Samuels and Shugart, 2010) because the separation of legislative and executive powers can affect voters' perceptions by multiplying the potential contradictory signals associated with party labels and positions. With presidential candidates offering their own political positioning (Arnold, Doyle and Wiesehomeier, 2017), these may provide differing information from other party organs (Kitschelt, 1999; Kitschelt and Wilkinson, 2007; Carlin, Singer and Zechmeister, 2015)

Third, federalism also adds complexity to political accountability relationships, as the 
existence of multi-level governance affects the clarity of party labels (Anderson, 2006; Carey, 2009). For example, parties operating across the regional electoral environments within a federal state can be associated with an array of different subnational identities (Chhibber and Kollman, 2009; Hicken, 2009).

The potential role of the party system in promoting clarity is multifaceted. One possible party system factor is sheer party fragmentation. On one hand, it is possible that a large number of parties could add complexity to the task of identifying positions (Dahlberg, 2013). On the other hand, more fragmented multi-party systems per se may promote competitive differentiation that could enhance the importance of ideological information (Dahlberg, 2009, 2013).

A more precise notion of party differentiation to promote clarity is captured directly by party ideological polarization, in which clear separations between ideological positions should facilitate voters' perceptions about party systems (Levendusky, 2009, 2010; Iversen and Soskice, 2015; Zechmeister and Corral, 2012; Ezrow, Tavits and Homola, 2013; Lupu, 2014). While the expected effect of party fragmentation is somewhat ambiguous, the distance between parties has clear implications. If parties are generally further apartthat is, more polarized - it should be easier for citizens to distinguish parties from one another (Levendusky, 2009, 2010) and the less that political sophistication should provide an advantage.

\section{Data and Methods}

\section{Data and Sample}

The data used for this study come from the three modules of the Comparative Study of Electoral Systems (CSES). A key benefit of these data are that they provide left-right placement data for a wide variety of countries, including both established democracies and 
newly democratized countries in Europe, Latin America and Asia. This variation enables us to assess how a range of country-level characteristics interact with individual-level characteristics to affect voters' perception of party systems.

We include 104 election surveys in total containing 169,788 respondents in 43 countries (Table 1). This sample includes all respondents who respond to at least 4 party stimuli along with the self-reported ideology question within all of the democratic countries in CSES. From the original 129 surveys, we exclude 12 country-years because of an insufficient number of party stimuli. ${ }^{1}$ We also exclude 13 election surveys from non-democratic countries and election years during non-democratic periods ${ }^{2}$.

${ }^{1}$ Belgium 2003, Chile 1999, Russia 2000, Spain 2004, Taiwan 1996/2008, Thailand 2001, United Kingdom 1997-2005, United States 1996-2008.

2 Belarus 2001-2008, Hong Kong 1998-2008, Kyrgyzstan 2005, Mexico 1997, Peru 2000 , Russia 1999-2004, South Africa 2009, and Thailand 2007. For this classification, we rely on Cheibub's Democracy and Dictatorship data. https://sites.google.com/site/ joseantoniocheibub/datasets/democracy-and-dictatorship-revisited (Cheibub, Gandhi and Vreeland, 2010) 
Table 1: Data Structure of the CSES

\begin{tabular}{lrrr}
\hline Data & N of respondents & N countries & N survey years \\
\hline CSES 1-3 (1996-2011) & 205,525 & 51 & 129 \\
CSES 1 (1996-2002) & 62,409 & 33 & 39 \\
CSES 2 (2001-2006) & 62,953 & 38 & 40 \\
CSES 3 (2005-2011) & 80,163 & 41 & 50 \\
& & & \\
Sample of Eligible Cases (1996-2011) & 169,788 & 43 & 104 \\
\hline
\end{tabular}

Note: i) CSES included two different surveys in Germany for 2002. The first one is a telephone survey and the second one is mail survey. ii) CSES included two different surveys in Belgium for 1999. One is conducted in Wallonia and the other one in Flanders. iii) The Portugual 2002 survey appears in both module 1 and 2 . We consider only the data in module 1. 


\subsection{Methodology}

For our dependent variable, we must measure an individual's ability to perceive party ideological location information and identify party positions within a party systems us-

ing survey data. A challenge to measuring the responses of voters' left-right ideological information is that of "differential item functioning" (DIF) in survey data (Aldrich and McKelvey, 1977; Brady, 1985, 1989). This refers to the problem of different respondents interpreting a question or concept differently. One approach to this that can be applied to many existing surveys is Aldrich-McKelvey scaling (Aldrich and McKelvey, 1977; Palfrey and Poole, 1987; Armstrong et al., 2014; Hare et al., 2015; Saiegh, 2014; Lo, Proksch and Gschwend, 2014), which makes use of individuals' self-placements. Aldrich-McKelvey scaling uses the relationship between individual self placements on a left-right scale and common stimuli (parties, politicians) on the same scale to adjust for the perceptual bias that occurs due to one's own positional perspective, thus enabling each respondent's perception to be compared in generating an estimate for the overall perceived location of the stimuli. Using this adjusted scaling output we can then generate a degree of deviation between the individual respondent's perceived locations and those recognized in the political system. The Comparative Study of Electoral Systems (CSES) provides the left-right self placement and party placement necessary for this. A Bayesian implementation of Aldrich-McKelvey scaling proposed by (Hare et al., 2015) enables application to data sets with missing stimuli response data, as is present in the CSES data.

\subsection{Adjusting for Perceptual Distortion Aldrich-McKelvey Scal- ing}

As noted above, we aim to generate comparable estimates of party placements that allow us to compare the accuracy of these placements across respondents. The purpose of Aldrich-McKelvey Scaling is to estimate the common stimuli behind reported ideological 
placement on a one-dimensional left-right scale, while accounting for individual perceptual distortion in survey data. This method involves estimating latent common stimuli, calculating individual perceptual distortion, and adjusting individual left-right self placements. Let $z_{i j}$ be the reported parties' left-right placement $j(j=1, \ldots, q$ by individual $i(i=1, \ldots, n)$. This method treats voters' reported left-right party positions as a linear function of these "true" stimuli positions $\left(\zeta_{j}\right)$ and error term $\left(\mu_{i j}\right)$, as follows.

$$
z_{i j}=\alpha_{i}+\beta_{i} \zeta_{j}+\mu_{i j}
$$

The weight term $\left(\beta_{i}\right)$ and intercept term $\left(\alpha_{i}\right)$ reflect voters' perceptual distortion about party positions in political space. The intercept term $\left(\alpha_{i}\right)$ indicates the extent to which respondents tend to bias their party positions rightward or leftward. The weight term $\left(\beta_{i}\right)$ captures voters' capacity to recognize party positions overall. Bias-corrected individual ideal points can be obtained as follows.

$$
x_{i}=\alpha_{i}+\beta_{i} z_{i(s e l f)}
$$

The result is intended to place parties' positions accounting for these perceptual distortions, in a common space. Here we examine the correlation between the scaled party stimuli locations with the individual party placement responses. We use the Bayesian implementation of Aldrich-McKelvey Scaling proposed by Hare et al. (2015), which allows nearly $90 \%$ of the of respondents' to be included in the estimation of the stimuli, despite individuals missing some stimuli ${ }^{3}$.

\footnotetext{
${ }^{3}$ The estimation process is described in detail within the Appendix. From the total 169,788 CSES observations, 139,229 include the self-placement data required to perform Aldrich-McKelvey scaling. Of these only 100,435 (72.13\%) provide complete responses for all stimuli. Applying the minimal response threshold of four stimuli, we retain 125,224 (89.94\%) of respondents in the estimation process that generates the dependent variable.
} 
We first calculate the correlation between the reported individual party placements and the estimated party stimuli locations, similar to the approach used by Palfrey and Poole (1987). For each individual $i(i=1, \ldots, n)$, we compute correlation coefficients between reported party placement $z_{i j}$ and estimated party stimuli $\zeta_{j}$ as follows.

$$
\rho\left(z_{i j}, \zeta_{j}\right)=\frac{\operatorname{Cov}\left(z_{i j}, \zeta_{j}\right)}{\operatorname{SD}\left(z_{i j}\right) \operatorname{SD}\left(\zeta_{j}\right)}
$$

The resulting correlation coefficients are intended to capture the accuracy of party position perceptions with regard to left-right perceptions. High correlations imply that perceptions are relatively accurate while low or negative correlations indicate that estimated party stimuli and a respondent's original response is very different, suggesting a lack of information about political party ideology. Since the original correlation coefficients range from -1 to 1 and are skewed rightward, we transformed this score by Fisher's

$\mathrm{Z}$ transformation such that our dependent variable is $\frac{1}{2}\left\{\ln \left(1+\rho_{i}\right)-\ln \left(1-\rho_{i}\right)\right\}$. The resulting transformed correlation coefficient scores range from about -0.5 to +2.5 and are nearly normally distributed with mean of 1.24 and standard deviation of 1.07.

\subsection{Independent Variables}

\section{Individual sophistication}

In our research design, we are interested demonstrating how country-level factors affect the overall supply and clarity of the information citizens have about party ideological locations and how these factors conditions the effect of individual sophistication. This is measured via educational attainment, which we treat as a proxy for the individual sophistication associated with greater demand for information on party ideological positions. We analyze this relationship by using interaction terms between the individual education level variable and country-level variables. To facilitate this, we make a binary variable for education level, which is designed to standardize and simplify the education measure across cases- 
identifying citizens who likely have a relatively higher demand for political information. In the CSES, the education level of the respondent consists of 8 categories about individual education leve ${ }^{4}$. We generate from this a binary variable of relatively 'high' education and 'low' education within each country-year. Specifically, those who are equal or greater than the country median education level are coded as 1 , and otherwise coded 0 . This binary education variable is used to interact with the system-level variables described in the following sections.

\section{Structural Factors influencing the supply of information}

Democratic Experience. Most importantly, we consider the degree of experience with democracy, which we use to capture the quality of party system information that may emerge in the process of the institutionalization of the party system. Because this is often connected to the distinction between 'new' and 'established' democracies, we capture this with years of democratic experience in the current democratic period. We use Cheibub's Democracy and Dictatorship data (Cheibub, Gandhi and Vreeland, 2010) to obtain the years since democratic transitions.

Programmatic Linkage between Voters and Parties. To assess the degree to which the party system provides programmatic party labels, we use the interaction between individual education and programmatic linkage between voters and parties (Kitschelt, 2000; Kitschelt and Wilkinson, 2007). We make use of Kitschelt's Democratic Accountability and Linkages Project Data (Kitschelt and Freeze, 2010; Kitschelt and Kselman, 2010, 2013), specifically the General Level of Effort variable which captures politicians' emphasis on "preferential benefits" at the country level, as opposed to programmatic policy

${ }^{4}$ The 8 categories consist of the following: 1 None, 2 Incomplete primary, 3 Primary completed, 4 Incomplete secondary, 5 Secondary completed, 6 Post-secondary trade/vocational school, 7 University degree incomplete, and 8 University undergraduate degree completed. 
positions. This variable comes from an expert survey and ranges from 1 to $4 .{ }^{5}$ Kitschelt's data aggregates individual expert responses into a continuous country-level variable that we use to capture this concept.

\section{Institutional and partisan Factors influencing the clarity of information}

Presidentialism. The first institutional variable we examine is the presence of a presidential system, which we expect might reduce the clarity of party labels by separating presidential and legislative parts of the party system. We code presidential systems dichotomously. ${ }^{6}$

Federalism. Second, we consider the effect of federalism, which also affects the linkage between voters and parties and clarity of party labels by introducing regional venues for party competition that can complicate the clarity of national party labels. We use the CSES code for the 9 federal countries in the sample. ${ }^{7}$

Effective Number of Electoral Parties. Further, we examine the interaction between individual education with the quantitative aspect of party systems. Following the existing research about party systems, we utilize the effective number of electoral parties, following Taagepera (1997).

${ }^{5}$ The original question ("b6") is as follows: "In general, how much effort do politicians and parties in this country make to induce voters with preferential benefits to cast their votes for them?" The answers are the following four categories: 1 A negligible effort or none at all, $2 \mathrm{~A}$ minor effort, $3 \mathrm{~A}$ moderate effort, and $4 \mathrm{~A}$ major effort.

${ }^{6}$ For the semi-presidential cases, we classify premier-presidentialism into the pure parliamentary category and president-parliamentarism into the presidential category. We rely on Robert Elgie's website http://www.semipresidentialism.com/to classify semipresidential countries.

${ }^{7}$ Australia, Belgium, Brazil, Canada, Germany, Mexico, Russia, South Africa, Switzerland 
Party Polarization. Another aspect of the party system affecting the supply of information is polarization. Here, our intent is to capture whether parties are sufficiently separated, in general, to better enable the identification of labels by voters. To examine this, we make use of a party system polarization index developed by Dow (2001), Alvarez and Nagler (2004), Dalton (2008), and Lupu (2014). The index is calculated by summing the distances between each party's position and the average party position and weighting these distances by party sizes. Along these lines, Lupu (2014) computes polarization following Dalton (2008) by calculating the standard deviation of the expert party positions generated in the CSES expert survey weighted by the vote share of each party. We use this score to measure party polarization.

Electoral System. As we note above, the party-centric nature of an electoral system may enhance the clarity of party labels. We therefore wish to test for any interaction effect between individual-level education and the electoral system type. While there are many possibilities with regard to electoral systems categories, we break them into the five relatively homogeneous groupings based on intra-party characteristics that should allow us to uncover any patterns: 1. closed list PR, including mixed-member proportional representation $(\mathrm{CLPR})^{8}$, 2. flexible-list PR (party-ordered lists that can be influenced by preference voting); 3. open list PR (with rank determined entirely by preference votes), 4. mixed member majoritarian systems (MMM, with independent nominal and closed party-list tiers), and 5. all forms of systems without party lists (where only candidates receive votes), including plurality, Alternative Vote, Single Transferable Vote and tworound systems.

${ }^{8}$ Closed list proportional representation includes cases of mixed-member proportional representation within a single category because the list tier is closed list and is the main factor in the allocation of seats. 


\section{Control Variables}

In addition to education level, we control for five additional individual variables from the CSES: age, gender, income level, closeness to a party, and political participation. We utilize individual respondent data from CSES. The first two variables, age and gender, are straightforward and we can use the original survey response. For the income variable, we transform the original categorical variable into a binary variable. Respondents equal or higher than the country median income are coded as 1 , otherwise as 0 . Further, we include two other micro-level variables related to political activity. These include a binary variable about general party identification ("Do you feel close to any political parties or not") and a

political participation measure from CSES, which refers to whether the respondent voted in the latest election. We also include one survey-level control for the number of stimuli, to account for any potential artifacts created by that quantity.

\section{Results}

Given the multilevel nature of the data, we use linear regression analysis with random intercepts for the survey/country-year groups. Table 2 shows the result of the analysis. The first column of this table includes a regression model with all variables described, without interactions, while the second introduces interactions with individual level education. Examining the first model, we note first that education levels have a statistically significant and a substantively large impact on the ability of citizens to identify the position of parties. Consistent with previous literature, we also find higher accuracy among older, male, and higher income respondents, as well as among party identifiers and those participating in the most recent election. 
Table 2: Determinants of Party Position Accuracy

\begin{tabular}{|c|c|c|c|c|}
\hline & Model 1 & & $\begin{array}{l}\text { Model } 2 \\
\text { (interactions) }\end{array}$ & \\
\hline & Coeff. & S. E. & Coeff. & S. E. \\
\hline Education & $.1992^{* * *}$ & $(.0086)$ & .0693 & $(.1015)$ \\
\hline Age & $.0012^{* * *}$ & $(.0002)$ & $.0010^{* * *}$ & $(.0002)$ \\
\hline Gender & $-.0658^{* * *}$ & $(.0069)$ & $-.0665^{* * *}$ & $(.0069)$ \\
\hline Income & $.1259^{* * *}$ & $(.0075)$ & $.1282^{* * *}$ & $(.0075)$ \\
\hline Close to a Party & $.0991^{* * *}$ & $(.0072)$ & $.0999^{* * *}$ & $(.0071)$ \\
\hline Political participation & $.1617^{* * *}$ & $(.0109)$ & $.1612^{* * *}$ & $(.0109)$ \\
\hline CLPR & $.3814^{*}$ & $(.1570)$ & $.3321^{*}$ & $(.1555)$ \\
\hline FLPR & .1846 & $(.1643)$ & .1553 & $(.1627)$ \\
\hline OLPR & .0906 & $(.1759)$ & .0839 & $(.1746)$ \\
\hline MMM & $.3129^{+}$ & $(.1899)$ & $.3746^{*}$ & $(.1890)$ \\
\hline ENEP & -.0105 & $(.0066)$ & $-.0126^{+}$ & $(.0066)$ \\
\hline Clientelistic Linkages & $-.2630^{* *}$ & $(.0916)$ & $-.2065^{*}$ & $(.0914)$ \\
\hline Polarization & $.0885^{* * *}$ & $(.0231)$ & $.0997^{* * *}$ & $(.0231)$ \\
\hline Presidentialism & -.0107 & $(.1315)$ & -.0908 & $(.1314)$ \\
\hline Federalism & $-.2414^{*}$ & $(.1094)$ & $-.3838^{* * *}$ & $(.1095)$ \\
\hline $\log ($ Democratic Experience) & .0548 & $(.0531)$ & -.0108 & $(.0531)$ \\
\hline Number of party stimuli & -.0404 & $(.0304)$ & -.0406 & $(.0298)$ \\
\hline Education $\times$ CLPR & & & .0299 & $(.0309)$ \\
\hline Education $\times$ FLPR & & & .0131 & $(.0315)$ \\
\hline Education $\times$ OLPR & & & -.0215 & $(.0361)$ \\
\hline Education $\times$ MMM & & & $-.1014^{*}$ & $(.0421)$ \\
\hline Education $\times$ ENEP & & & .0027 & $(.0017)$ \\
\hline Education $\times$ Clientelistic Linkages & & & $-.0727^{* *}$ & $(.0227)$ \\
\hline Education $\times$ Polarization & & & $-.0162^{* *}$ & $(.0053)$ \\
\hline Education $\times$ Presidentialism & & & $.0897^{* *}$ & $(.0317)$ \\
\hline Education $\times$ Federalism & & & $.1609^{* * *}$ & $(.0271)$ \\
\hline Education $\times \log ($ Democratic Experience $)$ & & & $.0828^{* * *}$ & $(.0129)$ \\
\hline Constant & $1.0035^{*}$ & $(.4328)$ & $1.1425^{* *}$ & $(.4315)$ \\
\hline Observations & 84695 & & 84695 & \\
\hline No. of Groups(Surveys) & 87 & & 87 & \\
\hline $\log ($ likelihood $)$ & -119707.87 & & -119523.00 & \\
\hline
\end{tabular}

Standard errors in parentheses, ${ }^{+} p<0.10,{ }^{*} p<0.05,{ }^{* *} p<0.01,{ }^{* * *} p<0.001$ 
While the direct effect of presidentialism is not statistically significant, we find that federalism is associated with less accuracy in discerning party positions. In addition, electoral systems have some direct effect, where the more candidate-oriented electoral systems - open list and non-list nominal systems - exhibit some tendency toward less accurate left-right perceptions when compared to closed-list systems. We do not find any relationships with party fragmentation. ${ }^{9}$ A clear effect is seen with polarization, however, a party-system factor regulating the clarity of information supplied to voters.

Our main interest here, however, is to determine whether system-level factors mediate the relationship with education. In the second column of 2 , we present a model with each system-level variable interacted with individual education level. In addition to the direct effect of polarization on increasing accuracy, we also see that more polarized systems seem to simplify the information needed for perceptual accuracy such that both high and low education respondents have a more similar ability to identify party placements. Taken together with the direct effect noted above, we find that polarization increases the ability of citizens to identify party ideology in general, but decreases the relevance of education in explaining this within-country variation.

Two variables we have investigated, the structural variables pertaining to democratic experience and clientelism, are intended to capture the underlying supply of ideological information from parties, either due to their institutionalization or programmatic nature. Without this supply, political sophistication should have less impact. Indeed, we find that democratic experience has an important conditioning effect of education, an effect shown in Figure 2. The difference between high and low education appears to be a phenomenon associated with experienced democracies, where the supply of party label information is

${ }^{9}$ It should be reiterated that our measure only differentiates among multi-party settings where CSES has provided four party stimuli and thus this does not capture all variation relevant to this variable. 
Figure 1: Marginal Effects of Education on Perceptual Accuracy, by Party Polarization

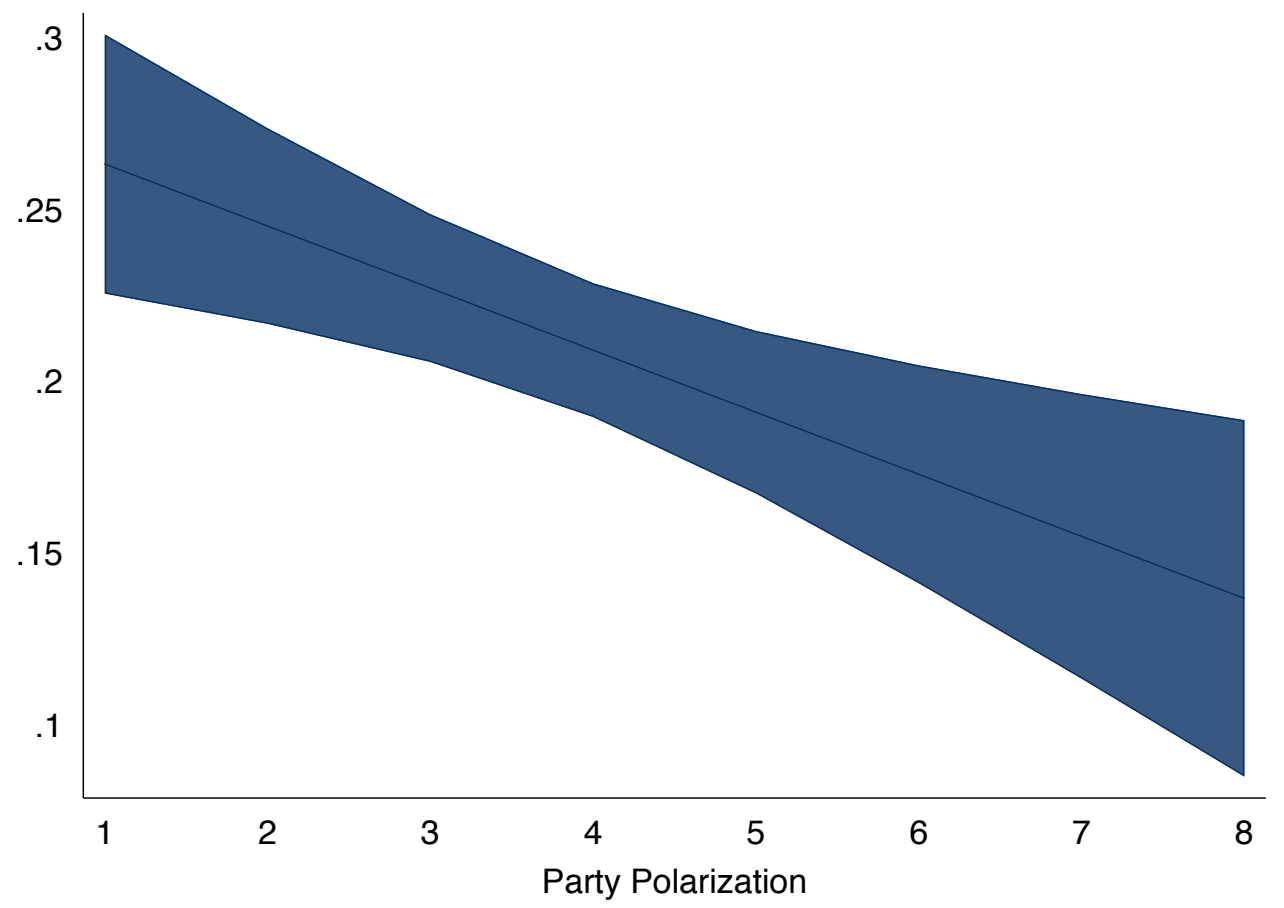

likely to be sufficient for informed voters to make use of it. Meanwhile, in new democracies, a greater demand for such information, as we expect from more educated voters, does not enable much greater ability to discern the ideological positions of parties. We interpret this to mean that new democracies provide too little information for consistent party placement, even for more educated voters. ${ }^{10}$

We examine a similar type of concept using our measure of the degree of clientelistic party linkages (i.e., politicians' emphasis on "preferential benefits"). Even while holding constant democratic experience, we find a similar effect for this variable. Education matters most in more programmatic party systems, where we would expect the supply of information would be greatest. In systems where clientelistic linkages appear to be ${ }^{10}$ We also considered a model including a closely related variable, the role of post-
communist legacies, which we found did not directly effect on the dependent variable nor
have a statistically significant interaction effect in models including democratic experience. 
Figure 2: Marginal Effects of Education on Perceptual Accuracy, by Democratic Experience

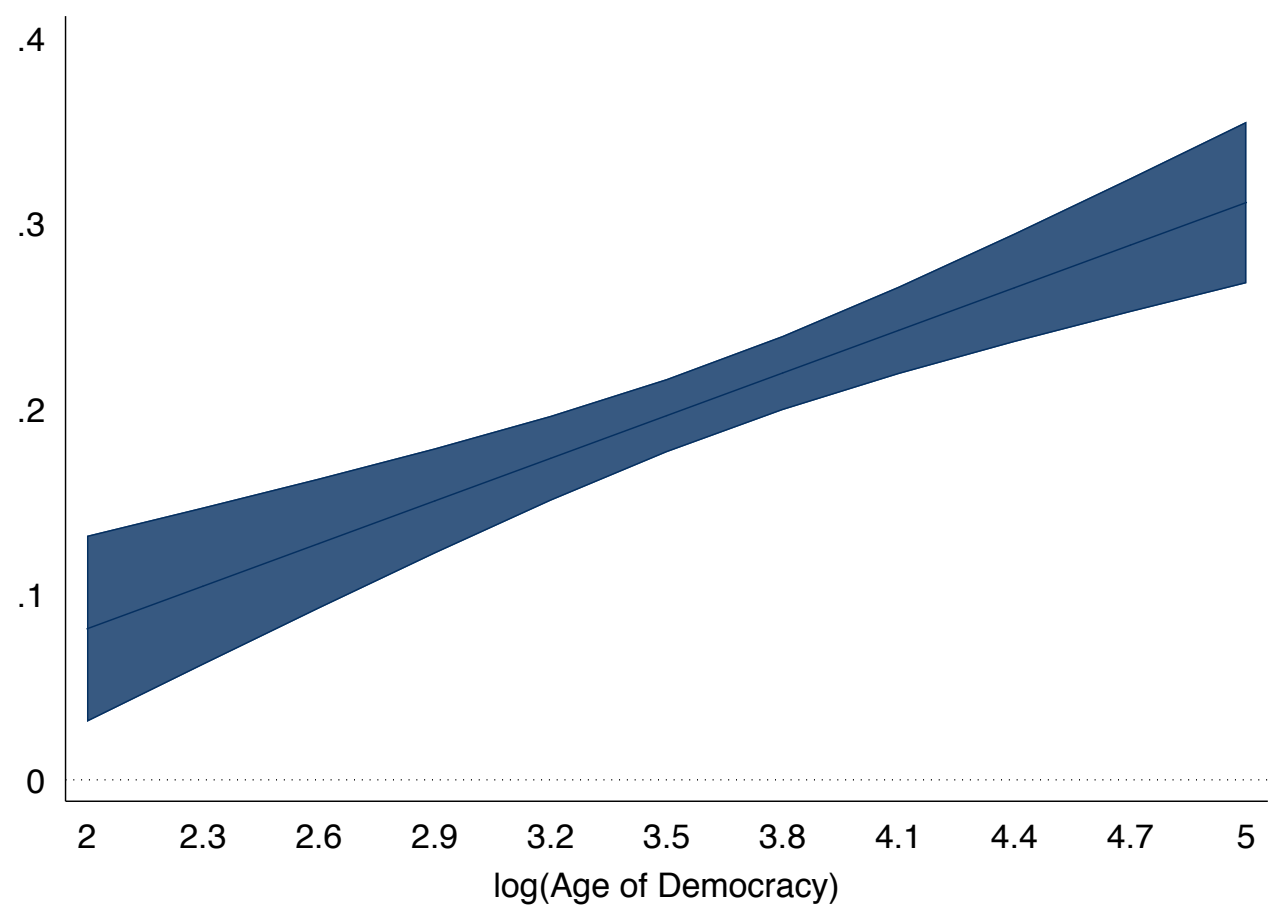


Figure 3: Marginal Effects of Education on Perceptual Accuracy, by Degree of Clientelistic Parties

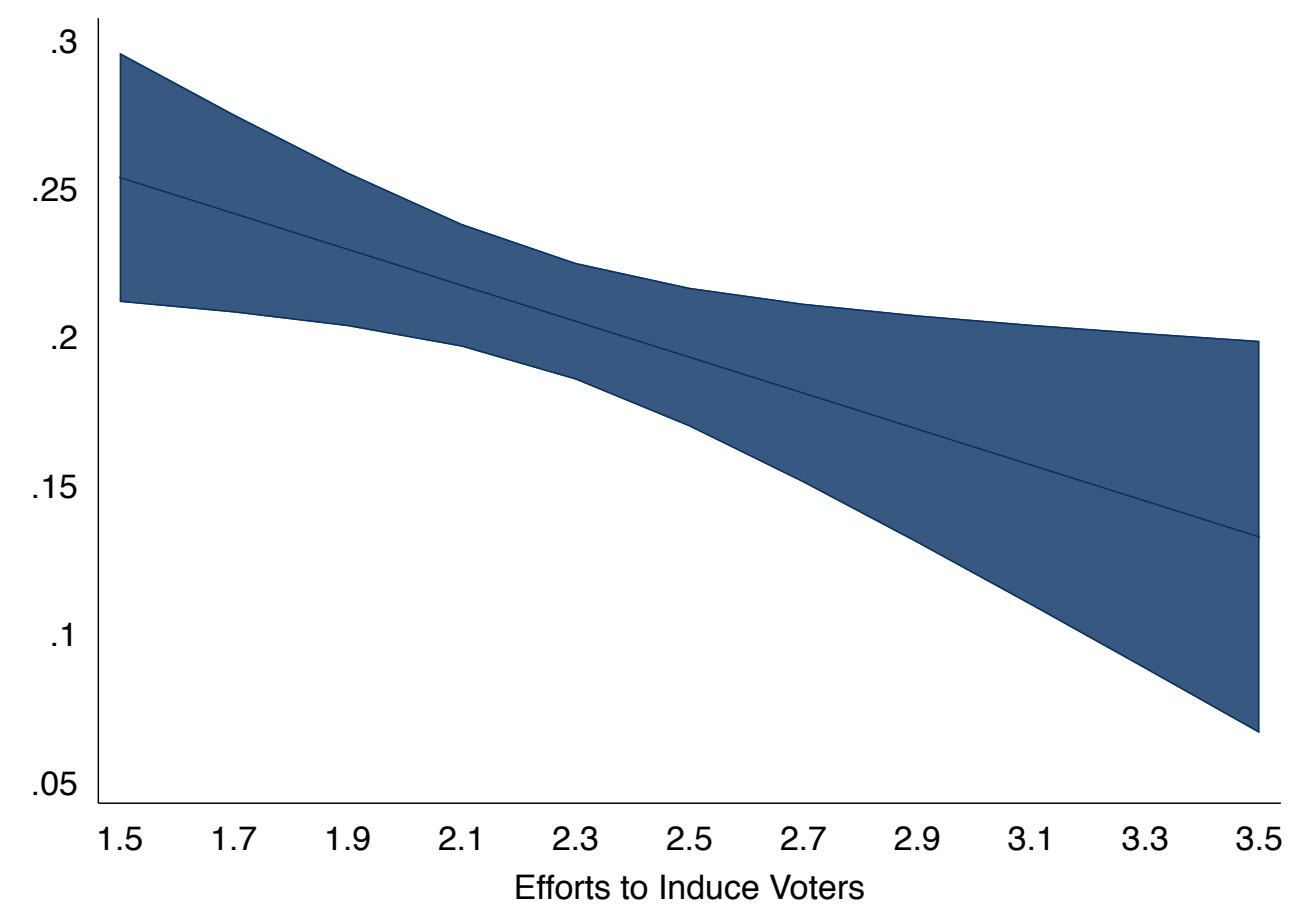

present (that is, with less programmatic parties), voters of all education levels have similar difficulty in discerning party positions. Figure 3 shows the declining marginal effect of education in predicting accuracy in left-right perceptions as the degree of clientelistic tendencies increase.

With regard to the constitutional features of presidentialism and federalism, we find that there is a stronger effect of education in both systems, suggesting that the complexity created by these contexts increases the gap between respondents with higher and lower education. We find that party fragmentation, however, does not condition the effects of education level to a statistically significant degree. Further, while electoral systems have a direct effect noted above, we do not generally find expected patterns regarding legislative electoral systems conditioning the effect of education. The effect is similar across types of systems, with the exception that the effect of education is weaker in the most diverse 
category, MMM.11

\section{Conclusion}

In this paper, we aim to understand how and when individual sophistication is most important to the accuracy of citizens' party placements. We identify and distinguish "supply" and "clarity" factors at the system level potentially influencing the quality and transmission of information about party labels. Using cross-national data from the Comparative Study of Electoral Systems (CSES) from democracies in all regions, we evaluate the basis for voter's ability to identify party ideological locations via an application of Aldrich-McKelvey scaling to a broad sample of self placement and party placement survey data.

With this approach, we examined how the effects of political sophistication-measured as relative educational attainment - vary across a wide variety of contexts. This has allowed us to determine whether these effects are enhanced or mitigated by certain institutional or party system features. Specifically, we sought to measure how the demand for information associated by political sophistication interacts with the supply and clarity of information provided by the overall electoral environment.

We find somewhat weaker average ability to place parties in contexts of federalism and less programmatic parties, and better average ability in closed-list and polarized systems. Most important, however, are our findings concerning the mediating role of factors that

\footnotetext{
${ }^{11}$ Although this finding suggests that MMM systems limit the effect of education, we emphasize caution in this interpretation as this category contains a series of unique systems with ambiguous overall institutional effects. Thus there is greater doubt in this category that this effect is related to the electoral system itself. The main purpose of including this distinction within the categorical scheme is to avoid pooling these unique cases within the other categories.
} 
influence the supply and clarity of party information. These contextual factors change the role that education level plays in citizen's perception of parties. With regard to factors affecting the supply of party information, our findings suggest that the political sophistication effects highlighted by advanced democracy research are likely limited to (or at least much stronger within) such cases. In the context of newer democracies and less programmatic democracies, political sophistication (education) appears to have little effect. Again, these environments do constrain the ability of voters to identify parties, on average. However, voters with various education levels seem to face this constraint to a similar degree in these less programmatic contexts.

In contexts where the clarity and complexity of party ideological information might be greater (under presidentialism and federalism) we see an increase the importance of sophistication, which is consistent with comparisons made between the US and Europe in previous literature (Listhaug, Macdonald and Rabinowitz, 1994; Granberg and Holmberg, 1988). Similarly, we also find that party polarization, which generally enhances the overall ability to discern among party positions, reduces the importance of educational differences among voters.

Our findings suggest that the persistent effects of sophistication throughout the literature on advanced democracies are in many cases dependent on contextual factors. While these differences could be interpreted as form of inequality in programmatic representation, these differences can also be seen as reflecting the quality of programmatic competition in advanced democracies countries. Meanwhile, our findings suggest that the least complex electoral environments do substantially mitigate these disparities. Conversely, the democratic benefits of horizontal and vertical separations of power may also be bring along potential challenges for uniformity in citizens' engagement in policy-based political choices. 


\section{References}

Adams, James F, Samuel Merrill III and Bernard Grofman. 2005. A Unified Theory of Party Competition: A Cross-National Analysis Integrating Spatial and Behavioral Factors. Cambridge University Press.

Adams, James, Michael Clark, Lawrence Ezrow and Garrett Glasgow. 2004. "Understanding change and stability in party ideologies: Do parties respond to public opinion or to past election results?" British Journal of Political Science 34(04):589-610.

Aldrich, John H and Richard D McKelvey. 1977. "A Method of Scaling with Applications to the 1968 and 1972 Presidential Elections." The American Political Science Review pp. 111-130.

Alvarez, R Michael and Jonathan Nagler. 2004. "Party system compactness: Measurement and consequences." Political Analysis 12(1):46-62.

Anderson, Cameron D. 2006. "Economic voting and multilevel governance: a comparative individual-level analysis." American Journal of Political Science 50(2):449-463.

Armstrong, David A, Ryan Bakker, Royce Carroll, Christopher Hare, Keith T Poole, Howard Rosenthal et al. 2014. Analyzing Spatial Models of Choice and Judgment with R. CRC Press.

Arnold, Christian, David Doyle and Nina Wiesehomeier. 2017. "Presidents, Policy Compromise, and Legislative Success." The Journal of Politics 79(2):380-395.

Brady, Henry E. 1985. "The perils of survey research: Inter-personally incomparable responses." Political Methodology 11(3/4):269-291.

Brady, Henry E. 1989. "Factor and ideal point analysis for interpersonally incomparable data." Psychometrika 54(2):181-202.

Brady, Henry E, Sidney Verba and Kay Lehman Schlozman. 1995. "Beyond SES: A resource model of political participation." American Political Science Review 89(02):271294.

Budge, Ian. 2012. Organizing democratic choice: Party representation over time. Oxford University Press.

Campbell, Angus, Philip E Converse, Warren E Miller and E Donald. 1960. "Stokes. The american voter." New Yrok: John Wiley and Sons p. 77.

Carey, John M. 2009. Legislative Voting and Accountability. Cambridge University Press.

Carey, John M and Matthew Soberg Shugart. 1995. "Incentives to cultivate a personal vote: a rank ordering of electoral formulas." Electoral studies 14(4):417-439. 
Carlin, Ryan E, Matthew M Singer and Elizabeth J Zechmeister. 2015. The Latin American voter: Pursuing representation and accountability in challenging contexts. University of Michigan Press.

Carpini, Michael X Delli and Scott Keeter. 1996. What Americans know about politics and why it matters. Yale University Press.

Cheibub, José Antonio, Jennifer Gandhi and James Raymond Vreeland. 2010. "Democracy and dictatorship revisited." Public Choice 143(1-2):67-101.

Chhibber, Pradeep and Ken Kollman. 2009. The formation of national party systems: Federalism and party competition in Canada, Great Britain, India, and the United States. Princeton University Press.

Conover, Pamela Johnston and Stanley Feldman. 1989. "Candidate perception in an ambiguous world: Campaigns, cues, and inference processes." American Journal of Political Science pp. 912-940.

Converse, Philip. 1964. "The Nature of Belief Systems in Mass Publics." Ideology and discontent pp. 206-61.

Dahlberg, Stefan. 2009. "Political parties and perceptual agreement: The influence of party related factors on voters' perceptions in proportional electoral systems." Electoral Studies 28(2):270-278.

Dahlberg, Stefan. 2013. "Does context matter-The impact of electoral systems, political parties and individual characteristics on voters' perceptions of party positions." Electoral Studies 32(4):670-683.

Dalton, Russell J. 2006. "Social modernization and the end of ideology debate: Patterns of ideological polarization." Japanese Journal of Political Science 7(01):1-22.

Dalton, Russell J. 2008. "The quantity and the quality of party systems party system polarization, its measurement, and its consequences." Comparative Political Studies 41(7):899-920.

Dalton, Russell J and Christopher J Anderson. 2011. Citizens, Context, and Choice: How Context Shapes Citizens' Electoral Choices. Oxford University Press.

Dalton, Russell J, David M Farrell and Ian McAllister. 2011. Political Parties and Democratic Linkage: How Parties Organize Democracy. Oxford University Press.

Dalton, Russell J and Steven Weldon. 2007. "Partisanship and party system institutionalization." Party Politics 13(2):179-196.

Dow, Jay K. 2001. "A comparative spatial analysis of majoritarian and proportional elections." Electoral Studies 20(1):109-125. 
Drummond, Andrew J. 2010. "Assimilation, contrast and voter projections of parties in left-right space: Does the electoral system matter?" Party Politics p. 1354068810376781 .

Duch, Raymond M. 2001. "A developmental model of heterogeneous economic voting in new democracies." American Political Science Review pp. 895-910.

Duch, Raymond M, Jeff May and David A Armstrong. 2010. "Coalition-directed voting in multiparty democracies." American Political Science Review 104(04):698-719.

Ezrow, Lawrence, Margit Tavits and Jonathan Homola. 2013. "Voter Polarization, Strength of Partisanship, and Support for Extremist Parties." Comparative Political Studies p. 0010414013512605.

Farrell, David M and Ian McAllister. 2006. "Voter satisfaction and electoral systems: Does preferential voting in candidate-centred systems make a difference?" European Journal of Political Research 45(5):723-749.

Gélineau, François. 2013. "Electoral accountability in the developing world." Electoral Studies 32(3):418-424.

Gomez, Brad T and J Matthew Wilson. 2006. "Cognitive heterogeneity and economic voting: A comparative analysis of four democratic electorates." American Journal of Political Science 50(1):127-145.

Gordon, Stacy B and Gary M Segura. 1997. "Cross-National Variation in the Political Sophistication of Individuals: Capability or Choice?" The Journal of Politics 59(01):126147.

Goren, Paul. 2004. "Political sophistication and policy reasoning: A reconsideration." American Journal of Political Science 48(3):462-478.

Granberg, Donald. 1987. "A Contextual Effect in Political Perception and Self-Placement on an Ideology Scale: Comparative Analyses of Sweden and the US." Scandinavian Political Studies 10(1):39-60.

Granberg, Donald and Sören Holmberg. 1988. The political system matters: Social psychology and voting behavior in Sweden and the United States. Cambridge University Press.

Grönlund, Kimmo and Henry Milner. 2006. "The determinants of political knowledge in comparative perspective." Scandinavian Political Studies 29(4):386-406.

Harbers, Imke, Catherine E de Vries and Marco R Steenbergen. 2013. "Attitude Variability Among Latin American Publics How Party System Structuration Affects Left/Right Ideology." Comparative Political Studies 46(8):947-967. 
Hare, Christopher, David A Armstrong, Ryan Bakker, Royce Carroll and Keith T Poole. 2015. "Using Bayesian Aldrich-McKelvey Scaling to Study Citizens' Ideological Preferences and Perceptions." American Journal of Political Science 59(3):759-774.

Hellwig, Timothy. 2008. "Explaining the salience of left-right ideology in postindustrial democracies: The role of structural economic change." European Journal of Political Research 47(6):687-709.

Hellwig, Timothy. 2014. "The Structure of Issue Voting in Postindustrial Democracies." The Sociological Quarterly 55(4):596-624.

Hellwig, Timothy and David Samuels. 2008. "Electoral accountability and the variety of democratic regimes." British Journal of Political Science 38(01):65-90.

Hicken, Allen. 2009. Building party systems in developing democracies. Cambridge University Press.

Hicken, Allen. 2011. "Clientelism." Annual Review of Political Science 14:289-310.

Hicken, Allen and Erik Martinez Kuhonta. 2011. "Shadows from the past: Party system institutionalization in Asia." Comparative Political Studies p. 0010414010396460.

Highton, Benjamin. 2009. "Revisiting the relationship between educational attainment and political sophistication." The Journal of Politics 71(04):1564-1576.

Horowitz, Shale and Eric C Browne. 2005. "Sources of Post-Communist Party System Consolidation Ideology Versus Institutions." Party Politics 11(6):689-706.

Huber, John D, Georgia Kernell and Eduardo L Leoni. 2005. "Institutional context, cognitive resources and party attachments across democracies." Political Analysis 13(4):365386.

Iversen, Torben and David Soskice. 2015. "Information, Inequality, and Mass Polarization Ideology in Advanced Democracies." Comparative Political Studies p. 0010414015592643.

Kedar, Orit. 2005. "When moderate voters prefer extreme parties: Policy balancingin parliamentary elections." American Political Science Review 99(02):185-199.

Keefer, Philip. 2007. "Clientelism, credibility, and the policy choices of young democracies." American journal of political science 51(4):804-821.

Kitschelt, Herbert. 1999. Post-communist party systems: competition, representation, and inter-party cooperation. Cambridge University Press.

Kitschelt, Herbert. 2000. "Linkages between citizens and politicians in democratic polities." Comparative political studies 33(6-7):845-879. 
Kitschelt, Herbert and Daniel M Kselman. 2010. The organizational foundations of democratic accountability: Organizational form and the choice of electoral linkage strategy. In APSA 2010 Meeting Paper.

Kitschelt, Herbert and Daniel M Kselman. 2013. "Economic development, democratic experience, and political parties' linkage strategies." Comparative Political Studies 46(11):1453-1484.

Kitschelt, Herbert and Kent Freeze. 2010. Programmatic party system structuration: Developing and comparing cross-national and cross-party measures with a new global data set. In APSA Annual Meeting, Washington, DC.

Kitschelt, Herbert, Kirk A Hawkins, Juan Pablo Luna, Guillermo Rosas and Elizabeth J Zechmeister. 2010. Latin American party systems. Cambridge University Press.

Kitschelt, Herbert and Steven I Wilkinson. 2007. Patrons, Clients and Policies: Patterns of Democratic Accountability and Political Competition. Cambridge University Press.

Klingemann, Hans-Dieter. 2009. The Comparative Study of Electoral Systems. Oxford University Press.

Lau, Richard R and David P Redlawsk. 2001. "Advantages and disadvantages of cognitive heuristics in political decision making." American Journal of Political Science pp. 951971.

Lau, Richard R and David P Redlawsk. 2006. How voters decide: Information processing in election campaigns. Cambridge University Press.

Levendusky, Matthew. 2009. The Partisan Sort: How Liberals Became Democrats and Conservatives Became Republicans. Chicago: University of Chicago Press.

Levendusky, Matthew S. 2010. "Clearer cues, more consistent voters: A benefit of elite polarization." Political Behavior 32(1):111-131.

Linzer, Drew A. 2011. The Left-Right Ideological Spectrum in Global Mass Opinion. In APSA 2011 Annual Meeting Paper.

Linzer, Drew Alan. 2008. The Structure of Mass Ideology and Its Consequences for Democratic Governance. ProQuest.

Listhaug, Ola, Stuart Elaine Macdonald and George Rabinowitz. 1994. "Issue perceptions of parties and candidates: a comparison of Norway and the United States." Scandinavian Political Studies 17(4):273-287.

Lo, James, Sven-Oliver Proksch and Thomas Gschwend. 2014. "A Common Left-Right Scale for Voters and Parties in Europe." Political Analysis 22(2):205-223.

Lupia, Arthur. 1994. "Shortcuts versus encyclopedias: information and voting behavior in California insurance reform elections." American Political Science Review 88(01):63-76. 
Lupia, Arthur and Mathew D McCubbins. 1998. The Democratic Dilemma: Can Citizens Learn What They Need to Know? Cambridge University Press.

Lupu, Noam. 2014. "Party Polarization and Mass Partisanship: A Comparative Perspective." Political Behavior pp. 1-26.

Lupu, Noam and Rachel Beatty Riedl. 2013. "Political Parties and Uncertainty in Developing Democracies." Comparative Political Studies 46(11):1339-1365.

Luskin, Robert C. 1987. "Measuring political sophistication." American Journal of Political Science pp. 856-899.

Luskin, Robert C. 1990. "Explaining political sophistication." Political Behavior $12(4): 331-361$.

Mainwaring, Scott and Edurne Zoco. 2007. "Political Sequences and the Stabilization of Interparty Competition Electoral Volatility in Old and New Democracies." Party politics $13(2): 155-178$.

McDonald, Michael D and Ian Budge. 2005. Elections, parties, democracy: Conferring the median mandate. Oxford University Press on Demand.

Merrill, Samuel and Bernard Grofman. 1999. A unified theory of voting: Directional and proximity spatial models. Cambridge University Press.

Merrill, Samuel, Bernard Grofman and James Adams. 2001. "Assimilation and contrast effects in voter projections of party locations: Evidence from Norway, France, and the USA." European Journal of Political Research 40(2):199-221.

Mondak, Jeffery J. 1999. "Reconsidering the measurement of political knowledge." Political Analysis 8(1):57-82.

Mondak, Jeffrey J. 2001. "Developing valid knowledge scales." American Journal of Political Science 45(1):224-238.

Neuman, W Russell. 1986. The paradox of mass politics: Knowledge and opinion in the American electorate. Harvard University Press.

Palfrey, Thomas R and Keith T Poole. 1987. "The relationship between information, ideology, and voting behavior." American Journal of Political Science pp. 511-530.

Poole, Keith, Howard Rosenthal, Jeffrey Lewis, James Lo and Royce Carroll. 2016. "basicspace: A package to recover a basic space from issue scales." $R$ package version $0.0 \%$. URL: http://CRAN. R-project. org/package= basicspace .

Poole, Keith, Jeffrey Lewis, Howard Rosenthal, James Lo, Royce Carroll et al. 2016. "Recovering a Basic Space from Issue Scales in R." Journal of Statistical Software 69(i07). 
Popkin, Samuel L. 1994. The Reasoning Voter: Communication and Persuasion in Presidential Campaigns. University of Chicago Press.

Powell, G Bingham. 2000. Elections as Instruments of Democracy: Majoritarian and Proportional Visions. Yale University Press.

Powell, G Bingham. 2013. "Representation in context: Election laws and ideological congruence between citizens and governments." Perspectives on Politics 11(01):9-21.

Powell Jr, G Bingham and Guy D Whitten. 1993. "A cross-national analysis of economic voting: taking account of the political context." American Journal of Political Science pp. 391-414.

Przeworski, Adam, Susan C Stokes and Bernard Manin. 1999. Democracy, Accountability, and Representation. Cambridge University Press.

Saiegh, Sebastián M. 2014. "Partisanship, Ideology, and Representation in Latin America.".

Samuels, David. 2004. "Presidentialism and accountability for the economy in comparative perspective." American Political Science Review 98(03):425-436.

Samuels, David J and Matthew S Shugart. 2010. Presidents, Parties, and Prime Ministers: How the Separation of Powers Affects Party Organization and Behavior. Cambridge University Press.

Samuels, David and Timothy Hellwig. 2004. Democratic regimes and accountability for the economy in comparative perspective. In Annual Meeting of the American Political Science Association, Chicago.

Schmidt, Gregory D. 2009. "The election of women in list PR systems: Testing the conventional wisdom." Electoral studies 28(2):190-203.

Shugart, Matthew Soberg. 2005. "Comparative electoral systems research: the maturation of a field and new challenges ahead." The politics of electoral systems pp. 25-55.

Shugart, Matthew Søberg, Melody Ellis Valdini and Kati Suominen. 2005. "Looking for Locals: Voter Information Demands and Personal Vote-Earning Attributes of Legislators under Proportional Representation." American Journal of Political Science 49(2):437-449.

Sniderman, Paul M, Richard A Brody and Phillip E Tetlock. 1993. Reasoning and choice: Explorations in political psychology. Cambridge University Press.

Stokes, Susan C. 2005. "Perverse accountability: A formal model of machine politics with evidence from Argentina." American Political Science Review 99(3):315.

Stokes, Susan C, Thad Dunning, Marcelo Nazareno and Valeria Brusco. 2013. Brokers, voters, and clientelism: The puzzle of distributive politics. Cambridge University Press. 
Strøm, Kaare, Wolfgang C Müller and Torbjörn Bergman. 2003. Delegation and Accountability in Parliamentary Democracies. Oxford University Press.

Taagepera, Rein. 1997. "Effective number of parties for incomplete data." Electoral Studies $16(2): 145-151$.

Thomassen, Jacques. 2005. The European voter: a comparative study of modern democracies. Oxford University Press on Demand.

Verba, Sidney and Norman H Nie. 1972. Participation in America: Political Democracy and Social Equality. New York: Harper and Row.

Verba, Sidney, Norman H Nie and Jae-On Kim. 1978. Participation and Political Equality: A Seven-Nation Study. New York: Cambridge University Press.

Warwick, Paul and Maria Zakharova. 2013. "Measuring the Median: The Risks of Inferring Beliefs from Votes." British Journal of Political Science 43(01):157-175.

Zakharova, Maria and Paul V Warwick. 2014. "The Sources of Valence Judgments The Role of Policy Distance and the Structure of the Left-Right Spectrum." Comparative Political Studies p. 0010414013516928.

Zechmeister, Elizabeth J and Margarita Corral. 2012. "Individual and contextual constraints on ideological labels in Latin America." Comparative Political Studies 46(6):675-701. 


\section{Appendix: Bayesian Aldrich-McKelvey Scaling Proce- dure}

As described above, we employ Bayesian Aldrich-McKelvey Scaling Hare et al. (2015) on the CSES mass survey data to derive a one-dimensional left-right-scaling from the selfreported ideological positions and party positions (stimuli). As noted, in the process of "correcting" the biases of self-reported ideology and party positions, this method reveals the voters' degree of distortion in perceptions of party positions. This enables us to generate for each respondent a correlation coefficient between the raw stimuli placement and scaled stimuli locations.

We estimate the key parameters $\alpha_{i}, \beta_{i}$, and $\zeta_{j}$ as follows. First, following Hare et al. (2015), we set uniform distributions for the prior of $\alpha_{i}$ and $\beta_{i}$.

$$
\begin{aligned}
& \alpha_{i} \sim U(-100,100) \\
& \beta_{i} \sim U(-100,100)
\end{aligned}
$$

Following Hare et al. (2015), we anchor the scaling process by choosing the leftmost party and the rightmost party stimuli. To establish these stimuli locations, we rely on the original implementation of Aldrich-McKelvey Scaling (Poole, Rosenthal, Lewis, Lo and Carroll, 2016; Poole, Lewis, Rosenthal, Lo, Carroll et al., 2016), which is restricted to the respondents who place all parties along with self placement. Identifying the left most and right most stimuli from that output, we constrain these stimuli in the Bayesian estimation by setting the most left stimulus $\zeta_{\text {left }}$ between -5.5 and -5 and the most right stimulus $\zeta_{\text {right }}$ between 5 and 5.5. The other priors for the "true" stimuli are normally distributed. We run two Markov chains, discard the first 10,000 MCMC iteration as burn in, store the subsequent 5000 and use the median (50th percentile) of the posterior distribution of these parameters $\left(\alpha_{i}, \beta_{i}\right.$, and $\left.\zeta_{j}\right)$.

$$
\begin{gathered}
\zeta_{\text {left }} \sim N(0,1) T(-5.5,-5) \\
\zeta_{\text {right }} \sim N(0,1) T(5,5.5) \\
\zeta_{j} \sim N(0,1)
\end{gathered}
$$

Because the original implementation of Aldrich-McKelvey scaling allows no missing values in placement of any party position, this would mean including only about $72 \%$ of available respondents in generating the stimuli estimates. In the Bayesian implementation, cases lacking a complete set of stimuli responses are still included in the process of generating the stimuli responses. As a result, nearly $90 \%$ of the of respondents' can be used in the estimation of stimuli locations for each country-year due to retaining individuals missing some stimuli. Missing stimuli data in the context of the MCMC process described above increases the uncertainty of point estimates, but we limit the effect of this uncertainty by only including respondents who had placed at least 4 party stimuli, both in the estimation of the stimuli and in the analysis presented above. We also examined a sample including only the individuals without missing stimuli responses and find results 
very similar to those reported in Table 2 . 
Table 3: Appendix: Determinants of Party Position Accuracy, Respondents with Complete Stimuli Responses Only

\begin{tabular}{|c|c|c|c|c|}
\hline & \multicolumn{2}{|c|}{ (Model 1) } & \multicolumn{2}{|c|}{$\begin{array}{c}\text { (Model 2) } \\
\text { (interactions) }\end{array}$} \\
\hline & Coeff. & S. E. & Coeff. & S. E. \\
\hline Education & $.1923^{* * *}$ & $(.0096)$ & .0579 & $(.1135)$ \\
\hline Age & $.0013^{* * *}$ & $(.0003)$ & $.0012^{* * *}$ & $(.0003)$ \\
\hline Gender & $-.0675^{* * *}$ & $(.0076)$ & $-.0685^{* * *}$ & $(.0076)$ \\
\hline Income & $.1335^{* * *}$ & $(.0083)$ & $.1357^{* * *}$ & $(.0083)$ \\
\hline Close to a Party & $.0977^{* * *}$ & $(.0079)$ & $.0980^{* * *}$ & $(.0078)$ \\
\hline Political participation & $.1714^{* * *}$ & $(.0122)$ & $.1708^{* * *}$ & $(.0122)$ \\
\hline CLPR & $.4042^{*}$ & $(.1663)$ & $.3478^{*}$ & $(.1653)$ \\
\hline FLPR & .2443 & $(.1741)$ & .2054 & $(.1729)$ \\
\hline OLPR & .1219 & $(.1864)$ & .0959 & $(.1856)$ \\
\hline MMM & $.3771^{+}$ & $(.2012)$ & $.4393^{*}$ & $(.2009)$ \\
\hline ENEP & -.0112 & $(.0070)$ & $-.0138^{*}$ & $(.0070)$ \\
\hline Clientelistic Linkages & $-.2685^{* *}$ & $(.0970)$ & $-.2206^{*}$ & $(.0974)$ \\
\hline Polarization & $.0867^{* * *}$ & $(.0245)$ & $.0997^{* * *}$ & $(.0245)$ \\
\hline Presidentialism & .0053 & $(.1393)$ & -.0562 & $(.1398)$ \\
\hline Federalism & $-.2304^{*}$ & $(.1160)$ & $-.3788^{* *}$ & $(.1166)$ \\
\hline $\log ($ Democratic Experience) & .0643 & $(.0563)$ & .0028 & $(.0565)$ \\
\hline Number of party stimuli & -.0412 & $(.0322)$ & -.0416 & $(.0316)$ \\
\hline Education $\times$ CLPR & & & .0401 & $(.0343)$ \\
\hline Education $\times$ FLPR & & & .0246 & $(.0351)$ \\
\hline Education $\times$ OLPR & & & .0053 & $(.0401)$ \\
\hline Education $\times$ MMM & & & $-.1006^{*}$ & $(.0462)$ \\
\hline Education $\times$ ENEP & & & $.0035^{+}$ & $(.0019)$ \\
\hline Education $\times$ Clientelistic Linkages & & & $-.0606^{*}$ & $(.0256)$ \\
\hline Education $\times$ Polarization & & & $-.0181^{* *}$ & $(.0059)$ \\
\hline Education $\times$ Presidentialism & & & $.0642^{+}$ & $(.0354)$ \\
\hline Education $\times$ Federalism & & & $.1678^{* * *}$ & $(.0308)$ \\
\hline Education $\times \log ($ Democratic Experience $)$ & & & $.0766^{* * *}$ & $(.0145)$ \\
\hline Constant & $.9238^{*}$ & $(.4587)$ & $1.0667^{*}$ & $(.4590)$ \\
\hline Observations & 69907 & & 69907 & \\
\hline No. of Groups(Surveys) & 87 & & 87 & \\
\hline $\log ($ likelihood $)$ & -98821.71 & & -98691.59 & \\
\hline
\end{tabular}

Standard errors in parentheses

${ }^{+} p<0.10,{ }^{*} p<0.05,{ }^{* *} p<0.01,{ }^{* * *} p<0.001$ 